\title{
Reflections on The Cinema Hypothesis: A response to Alain Bergala
}

\author{
Andrew Burn* - UCL Institute of Education, UK
}

\begin{abstract}
This article engages in debate with Alain Bergala's The Cinema Hypothesis. It selects four topics for discussion. The article agrees with Bergala's arguments for the importance of (film) art in education as a productively subversive practice, and that engagement with film should be a creative process, in the viewing and interpretation of film as well as in film-making. It disputes Bergala's opposition to language-isms, arguing for the value of multimodal semiotics as a way for students to understand the structures of the moving image. It also disputes Bergala's efforts to insulate film from other media, arguing that, in a world of proliferating transmedia narrative, educators and students benefit from exploring representations and structures between and across media.
\end{abstract}

Keywords: film education; media education; multimodality; semiotics; media literacy

Alain Bergala's treatise on film education, The Cinema Hypothesis (Bergala, 2016), engages with profound questions that have faced those of us involved in film education over the years, many of which continue to be pressing because they provoke debates both theoretical and practical, and also because they inspire and enthuse film educators (if not always policymakers). The contexts in which The Cinema Hypothesis is relevant are various. The most obvious is that of film education as a free-standing curriculum entity, despite the paucity of provision for this internationally, in Europe (Reid et al., 2013), but also in the rest of the world. The second context is the relationship between film education and media education, which is particularly strong in the UK. The third is the wider question of film and media literacy, which is not, for me, an exercise in vague metaphors, but a specific conceptual approach to moving image and other media, aligning them to sociocultural approaches to literacy more generally (Burn, 2009). These contexts frame some of my observations in this article, which will be a mix of specific debates with Bergala's thesis, and arguments of my own, more loosely provoked by The Cinema Hypothesis.

The Cinema Hypothesis is a book full of insight, of intellectual generosity as well as stern critique, infused with a lifelong dedication to cinema, both its theory and its practice, interdependent themes that recur throughout the book. For academics, it proposes robust debates with questions of film aesthetics, semiotics, cultural value and distinction. For film educators, it presents a rich array of practical advice, which touches on all the problems and conundrums many of us have faced, including: the elusive nature of the audience for whom children make films (Burn and Durran, 2007: 57); the perennial problems of storyboarding (Chandler et al., 2009: 7; Bazalgette, 2009: 16-17; Burn and Durran, 2007: 53-5); the dangers of pseudo-collaborative work premised on a simulation of the industry (Buckingham et al., 1995); and the virtues and vices of making fragments and shorts. 
It is a book whose great virtue is to oblige its readers to rethink their cherished beliefs, and then to rethink them again, testing them against experience, practice and peer debate. It is a provocative book in many ways, and I think it is intended to be so - it takes no prisoners, tolerates no vague rationale in theory or practice, respects no cherished shibboleth.

At its centre is the hypothesis itself. To engage fully with this would take a second treatise of comparable size, so I will select four aspects to discuss in this article.

\section{Otherness of art in education}

The first aspect is the proposal that Bergala attributes to Jack Lang, that 'arts education is centered on an encounter with otherness' (Bergala, 2016: 21). This could mean many things, but Bergala's account is distinctive. 'Otherness' here means, for example, a refusal for art to be obedient: 'Art, in order to remain art, must remain a catalyst for anarchy, scandal, disorder' (ibid.).

Nothing could be further from the insistence on 'pro-social' purposes for creativity and the arts in education typically proposed by government policy in the UK. Indeed, when children do employ art as a vehicle for scandal and disorder - or even simply critique of the establishment in which they are educated - their expressions can be challenging for the official culture of schools, as research into the UK's Creative Partnerships programme demonstrated (for example, Thomson and Hall, 2015). Bergala's formulation reminds me of Brian Sutton-Smith's fierce insistence on the phantasmagoric nature of children's play, in defiance of the adult belief that it's only a rehearsal for future good citizenship, the developmental argument that SuttonSmith calls the rhetoric of progress (Sutton-Smith, 2001). Nevertheless, I feel a word of caution is in order here. It can be easy for the argument for phantasmagoria and anarchy to slip into a romantic celebration of these qualities. Although less immediately attractive, perhaps the ideal model needs to allow for both Being and Becoming, in the phenomenological formula adopted by the new sociology of childhood (Uprichard, 2008) to represent the ambiguous nature of childhood - a state that is autonomous and self-sufficient, yet always on a trajectory to another state. In the case of film education, then, as well as the arts in general, the artistic medium of the moving image can enable whatever dissident, subversive, anarchic meanings children might want to make, yet can also serve as a kind of art-apprenticeship necessitating a journey from inexperience to experience. Indeed, Bergala's method suggests this. The argument for otherness exists in some tension with the emphasis on the teaching of formal film structures, but such a tension can be entirely productive, managed sensitively with attention to diversity of cultural interests and aesthetic preferences. In the same spirit, Bergala (2016: 21) proposes that art cannot be understood by the student without 'contact with the artist, the craftsperson, like a foreign body in the classroom, like a pleasantly disruptive influence in the school's value system'.

This is an attractive proposition, and many teachers in the arts would recognize and applaud it. However, it also needs some consideration of the role of the arts teacher, or perhaps the teacher-as-artist. Music and art teachers are invariably musicians and artists, and to some extent we could say the same of teachers of drama and dance. It is not always the case, however, with the teacher of the literary arts or the media arts, including film. There is a good argument that it should be the case, however; in that case, the artist who visits the classroom must negotiate both creative skill and pedagogy with the teacher. And the terms of such a negotiation, the principles to be agreed, the practices to be adopted, could be derived from much of The Cinema Hypothesis. 
To consider not only artists, but teachers of the arts in this light, as 'pleasantly disruptive' influences, is to honour a long-standing feature of their identity. Richard Johnson, of the Birmingham Centre for Contemporary Cultural Studies, once said something similar about media teachers, characterizing them as internal critics, productively disruptive of the institution (Johnson, 1989). Meanwhile, there is a longstanding tradition of the need for teachers of the arts to practise the art they teach, for their own development and personal renewal, and to understand the work of their students better, as Thompson (1986) argues.

\section{A generalized pedagogy of creation}

A second feature of Bergala's (2016: 24) hypothesis is a refusal of the division between analysis and production. In his words, 'I am convinced that there is not ... a pedagogy of the spectator ... and a pedagogy of the film-maker'; instead, he suggests 'a generalized pedagogy of creation'.

In later chapters, he goes on to demonstrate how the act of reading film can be seen as creative in its own right, an effort to see the film from the point of view of the creative act of the film-maker; and later, how the principles derived from such appreciation can inform film-making in schools. The division between analysis and production has been a perennial plague of film and media education in the UK, at its worst producing a schism between mechanistic shot-type spotting and intuitive creative work that, whatever its merits, may lack an understanding of the formal properties of the moving image.

However, there has also been much good work that has effectively overcome this division. My ideal examples often come from the work of my former colleague James Durran, who produced some powerful approaches to teaching Hitchcock to GCSE students, which effectively combined creative and analytical work. One example was pouring the whole of Psycho (1960) into Microsoft's Movie Maker editing tool, which at the time had an automatic shot-detection function, splitting the whole film into hundreds of individual shots. These could then be viewed as thumbnails, and easily grouped, put together on the timeline in a rough edit, and viewed, sorted, remade and manipulated. A digital unstitching of the fabric of the film enabled taxonomical work, attention to film form and narrative structure, and consideration of the relation between sound and image to be conducted through a manipulation of the digital material of film itself. We saw it as a kind of digital anatomy, less like a semiotic analysis (though semiotics had its place) than like Michelangelo's illicit raids on Florentine morgues to dissect and understand the human form (Burn and Durran, 2006).

Here is an example from one of James's classes - slides from a much longer PowerPoint essay by a 13-year-old, looking not only at the modes of language, music and dramatic action as well as the orchestrating functions of shot construction, but also at the implied movement of the stuffed bird on the wall. This seems to me a good example of the creative appreciation Bergala calls for - it exceeds conventional film semiotics, notes the kind of third meaning Barthes (1978) identified, perhaps, but avoids vague generality.

The first slide (Figure 1) observes the distance of the camera from Marion and Norman, and the connection established between them through their position in the respective frames, across the shot divide. It notes how the music reappears when they enter. It is descriptive, rather than interpretative - but it accompanied a spoken presentation that made the interpretative leap. 
The second slide (Figure 2) is rather different, and focuses on the stuffed bird on the wall, its wings outstretched. Here is an inferential reading, proposing the bird as a metaphor for either Norman or Marion.

Music comes back as soon as they enter the parlour

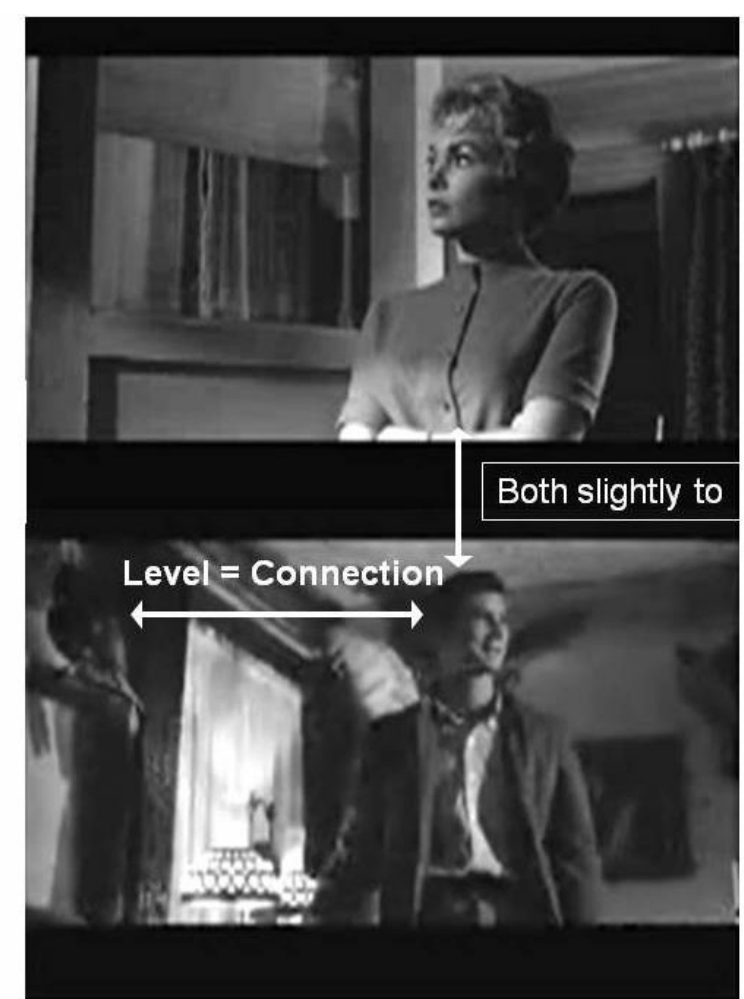

Figure 1: Slide from a 13-year-old student's PowerPoint 'essay' on Psycho

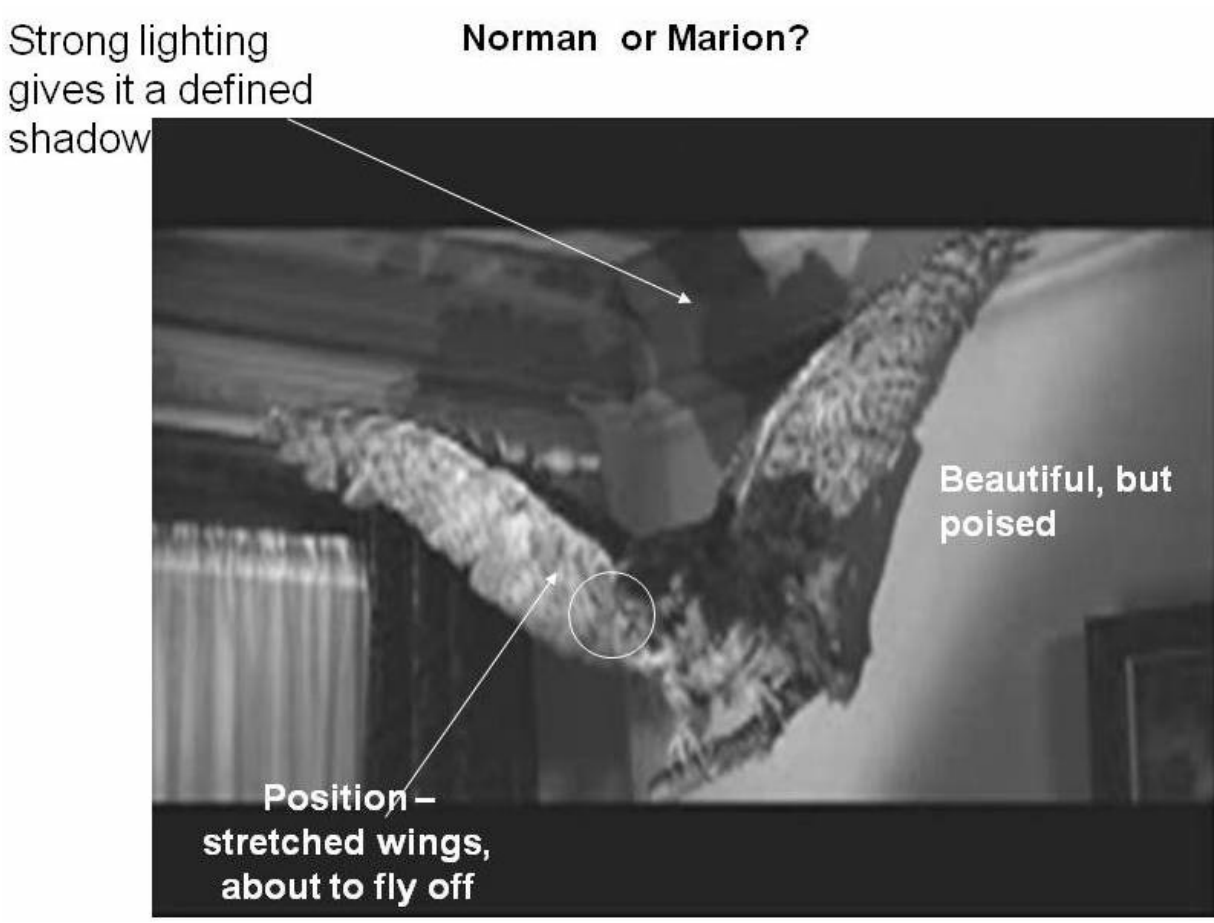

Figure 2: Slide from a 13-year-old student's PowerPoint 'essay' on Psycho 
This is, then, an anatomy of this part of the film, using digital editing tools to unpick the fabric of the film, representing shots with diagrammatic conventions and linguistic annotation. It is a kind of multimodal essay - but also creative. Essays, of course, can be creative in their own right, even when confined to the mode of written language, but the creativity here is multifaceted, since it plays with the stuff of the film itself. As I have argued elsewhere (Burn, 1999), it disrupts the narrative flow of the film in ways peculiar to the cinematic still, in Barthes's account (Barthes, 1978), but reworks the narrative object in its own aesthetic, signalling dispassionate interpretation (arrows, notes), but also the Grand Guignol of horror (it uses red for the backdrop throughout, for example). The second slide also attends to a marginal detail in ways reminiscent of Barthes's attention to the shower of gold coins in Ivan the Terrible (ibid.: 52), a third meaning detected by the spectator out of the corner of her eye, as it were. The difference, perhaps, is that Barthes constitutes this third dimension as transcendental, in an extra-semiotic domain, whereas this student contains it within the semiotic, identifying the elements of the image that suggest the meanings she infers.

The term 'creativity' is one I am anxious not to reify, however. It is heavily contested in the arts in general - no less in the media arts - and, in different ways, in education (Banaji et al., 2007). My preferred model of creativity is derived from Vygotsky (1998), who sees creativity as a development from play in childhood, which itself involves the imaginative transformation of cultural resources in material, social contexts - his wellknown example being a broomstick used as a horse by a child. To become a creative act proper, these acts of imaginative transformation would need to be subordinated to conceptual thought, such as the logic of narrative (my example). In the process, the imaginative work conducted in the external social world is internalized, and then returned to the social world in the creative act using semiotic tools, which can either be conceptual (for example, the concept of a close-up) or technological (for example, a camera or a digital editing timeline).

What we gain from such a specific model is some purchase on how conceptual understanding might relate to creative film-making. For example, if a child draws a storyboard, and constructs a frame as a long shot, and labels it ' $L / S$ ', there is a conjunction of the visual framing practices that will lead to the camera's action, and the idea of a shot type that articulates the spatial logic of the moving image, and what it can suggest about setting, emphasis, social proximity and so on.

More generally, we can distinguish such a conception of creativity from other rhetorics, whether these be of romantic genius, neurological events or problemsolving in the workplaces of the knowledge economy. The connections it makes possible between play and learning, imagination and rationality, thought and semiotic expression, all help us to understand creativity in education, and, in this case, the creative act of film-making.

To return to Bergala's hypothesis, these examples are intended to support his argument that creativity can be found not only in film-making, but in the viewing and interpretation of film. This insight is both simple and profound - and difficult to achieve, as my examples show. It requires not only a conceptual leap on the part of the educator to overcome the apparent divide between viewing and making, but also a complex pedagogy to interweave the two processes.

\section{Language-isms}

I have alluded briefly to semiotics, and so would like to consider the argument against language-ism proposed in The Cinema Hypothesis. 
To begin with, it is surely right that we should reject any kind of dry, pseudogrammatical analysis of film. I take Bergala's impatience with this to be analogous to the similar discussion about grammar in language teaching - that an emphasis on decontextualized grammar is the enemy of meaning, of the appreciation of the affective charge and aesthetic form of the artwork, of a passionate engagement with it (Wyse, 2001). From a different perspective, decontextualized grammar is unable to attend to the social contexts in which meaning is made, and the same applies to film. To use Psycho as the example again, how could we not recognize the social histories and moral panics that lie behind the rise of the slasher movie? Or the constraints that frame the figure of the female victim, the politics of representation that are unavoidable in this film, as in Hitchcock's other films?

However, this is not the argument Bergala makes. Rather, his two points are, first, that language-ism denies the single articulation of film, 'written from reality', in his quotation from Pasolini (1988), and, second, that it leads to specious ideological analysis.

Many film scholars may agree that the ultimate argument for a language-style grammar of film died with Metz's 'grande syntagmatique' (1974), although others would dispute this, of course. In my own work, I have found it more useful to consider how the moving image is composed through the use of multimodality theory (Kress and van Leeuwen, 2001; Burn, 2014). The idea here is that particular compositional principles can be detected - obvious examples are frame, rhythm, spatial disposition, temporal organization - which are tools of the artist, and have a level of abstraction beyond the concrete image. More importantly perhaps, they are common to the different modes that make up film - they run across music, language, dramatic gesture, sound, lighting and so on - the modes that Metz attempted to evacuate from his cinematic grammar of shot-sequences, but which Eisenstein generously accommodated in his vision of montage (Eisenstein, 1968). Multimodality has not so far made much impression on mainstream film theory - but Eisenstein can be seen as the original multimodalist, not merely because he attended to the juxtaposition of image and sound, movement and action, music and text, but also because he devised systems of diagrammatic notation of these elements that represented intersemiotic principles and patterns (secrethesis. wordpress.com, 2011).

Similar attention is paid in multimodal accounts of the moving image, such as van Leeuwen's (1985) essay on the rhythmic conjunction of speech, shot-editing and music in North by Northwest (1959), while the relation of multimodal articulations to cultural context can be seen in my own analysis of Olivier's Hamlet (1948) as an example of the 'kineikonic mode', or the moving image as multimodal assemblage (Burn, 2014).

However, Bergala's objection to language-isms is made specifically in the context of film education, so it is here that any challenge must be located. A good case can be made for the use of multimodal semiotics in the analysis, for research purposes, of children's film-making, which can reveal the intention of the young makers in different modes (for example, dramatic, musical, cinematic), and how these connect to produce the final effect (Burn, 2016). By the same token, in my view the work of film production must be rooted in an awareness of the multimodal nature of film for two reasons. First, not to do so is to privilege some modes unduly over others. If the work in question is a film drama, then the work of the actor to convey narrative through the embodied modes of spoken language, gesture, facial expression, proxemics, more-orless choreographed movement and so on seems to me to need as much attention as the mobility and positioning of the camera, or the ordering and stacking work of the 
editing timeline. The functions of filming and editing, not least in the hands of children, are indeed the modes that orchestrate all the other contributory modes, but they do this not by hijacking them, but by respecting and understanding them.

This is a tall order, both for teachers and students. It appears to mean that both need to acquire expertise, not only in the related arts of filming and editing, but also in drama, music, linguistics, lighting and so on. This is partly a practical matter, but more profoundly a matter of expertise, craft and the distribution of knowledge. Both practically and philosophically, there are two solutions. One is for teachers and learners to aim at a good enough general understanding of the modes in play and how they relate to each other, while making the most of differing levels of expertise in each of them: to consider who has used a camera, who attends a drama group, who plays a musical instrument, what the teacher studied at university and so on. In my experience, this produces a mix of skills and knowledge that, if unpredictable, at least expresses the character and aesthetic preferences of the group as a whole. The other solution is a planned interdisciplinarity: to regard the work itself as a multimodal collaboration, involving the film educator, the music teacher, the drama teacher, the language teacher and the IT teacher, and drawing on the students' experience across these domains (Burn, 2016).

The second reason for an explicit attention to the multimodal semiotics of filmmaking with young people is to cultivate a critical understanding of what they are doing. It seems to me impossible to avoid some kind of development of this kind, however much we may insist on the directness of the creative endeavour. To use the same example referred to above, working closely on a long shot would involve using the term itself, and for students to understand what such a shot accomplishes may - should - encompass how it represents figures in space, both in terms of the expanse of information (we see more of them, as in an establishing shot) and in terms of distance (social proximity). So it would be hard work to avoid the term 'long shot', and impossible to avoid the concepts that accompany it, concepts that become properly complex and revised through practical application. Indeed, as I have argued, in Vygotsky's model of creativity, it is impossible to separate such conceptual understanding from the imaginative transformations young film-makers will be conducting in sound and image.

However, if the long shot in question also includes a character walking towards the camera, do we simply leave it up to the young actor to decide on the pace, rhythm and style of the walk? On the expression on her face as she nears the camera? On the movement of her hands: freely swinging, in her pockets, brushing away a lock of hair? Or do these become part of the explicit process, a process in which the categories of 'critical' and 'creative' necessarily fuse? If so, then the multimodal semiotics of the moving image have entered the room, as it were. This is not language-ism in the dry sense, which is what I think Bergala is criticising. But it is semiotics in the sense of multiple articulation, across a range of modes. In fact, language-ism is a perennial thorn in the side of multimodality theory too, which is in the awkward position of owing part of its origins to sociolinguistics, while attempting to distance itself from language, the more accurately to represent other modes. Whether we call all this 'language-ism' does not really matter in the end. It seems to me to accommodate Bergala's insistence on the specificity of the photographic image, while finding common compositional principles with the other modes of the moving image. In this sense, of course, the principle of double articulation may still apply: it depends how you think about these principles. They may derive from the visual image, but they are certainly abstractly 
applied to denote social proximity, the expansion or contraction of time, the contiguity of space across shots and so on.

From a multimodal point of view, the 'written-from-reality' principle does not hold up well at all. As soon as a voice-over narrative, a dissolve transition, a line of music, a superimposed title, and all the other panoply of moving image composition is added in, the moving image is multiply articulated, and must be approached in this way, both for creation and for analysis. However, we can say that multimodality increasingly addresses the aesthetic as sense perception (Aristotle's original formulation), an emphasis Bergala rightly insists on. Multimodality considers the multisensorial, allowing us to unite the semiotic work of different modes with their apperception, and the sensory, affective engagement this demands. Finally, to push the multimodal thesis a little further, we can also look beyond film at cognate art forms - how such common principles of composition can travel across, broadly speaking, the narrative arts. This brings me to my fourth point: Bergala's discussion on what he calls 'Cinemaand' (Bergala, 2016: 25).

\section{Cinema-and}

Bergala's vigorous argument here is a vehement opposition to the careless bundling together of cinema with the audiovisual. In general terms, I agree with this. It is the wrong kind of bundling together - the wrong kind of alliance - and we see its damage in media literacy policy across the world, and especially in the EU, where it is more convenient to obscure the cultural and technological specificities of film, video games, radio and television by using the umbrella term 'audiovisual'. It is also a term that depends entirely on technical categorization, and so ignores other kinds of textual alliance, such as that existing between the narrative arts, and, most particularly, between literature and film.

However, this bundling is composed of many different kinds, and the most problematic to oppose is the relationship between film and television, which is Bergala's chief example. It is problematic for many reasons. One is that the two forms share the structures of the moving image. It would be hard to explain why students could not engage with, for example, the aesthetics of shot construction through television drama as well as through film. A second reason is the function of television as a platform for film, so that the distinctions are not so much about film itself but about the differences between large and small screen, cinema and living room. A third reason is the increasingly filmic nature of large television franchises such as Game of Thrones (2011-) and Peaky Blinders (2013-). The epic sweep, production values and quality of writing in these new kinds of television match the scale of film, and indeed exceed it in temporal reach.

But I want to argue for a different kind of 'cinema-and', which is not founded on the vagueness that Bergala rightly takes to task, but on specificity. Again, it is a multimodal argument - that there are common compositional principles shared across the narrative arts. These may be at some level of abstraction - framing, point of view, the ordering of space and time. In these respects, this is not a new story - after all, the concept of focalization travels from Genette's analysis of Proust to Chatman's analysis of film (Genette, 1980; Chatman, 1978). It is also one of the central questions of adaptation studies.

What is new, perhaps, is an even more specific focusing on the narrative art of video games, in which the operation of the camera shares some features with film, while other features are different, available to the roving eye of the player and to her 
controlling hand on the console, or in which the temporal sequence resembles the eternal present tense of film in certain respects, yet differs in its continuous flow, like an extended long take. To engage with these features across film and game, along with concepts such as point of view, seems to me only to strengthen young people's grasp of these principles, especially if they can make these forms through their own creative production as well as analyse them. Perhaps the best example of this in my own work was a consideration of how children understood and appreciated the mythos of Harry Potter across book, film and video game. At one level, this was about broad engagement with the narrative. At another, however, it was about a detailed understanding of how the agency of the protagonist altered when the player had control - a detailed appreciation of point of view and the narrative function of the protagonist. Most specifically, it provided a profound insight into the system of person in language, and how this principle transmuted across these media: why a thirdperson engagement with the character of Harry Potter means something different in book, film and video game (Burn, 2006). In terms of the media in general, this kind of experience relates to the nature of transmedia narrative, which Bergala's argument in general seems to preclude. To lock off film as a 'pure' art form is to ignore the complex relationship it has had with literature and theatre since its inception, and which it now has with television, video games, comic strips and other forms.

So, for me, there is a legitimate cinema-and - a complicity with sister narrative forms and the value of investigating this with young people. Bergala addresses a broader implication of this debate, arguing that the cinema-and, if associated, as it often is, with television, would result in something better located in civic instruction than in the arts. Again, my first instinct is to agree wholeheartedly, and a generalist location of film and the media more generally in civic education - or citizenship, if we translate it to the UK context - is to impose an adult view of the media as predominantly about information conveyed to young people. By contrast, their engagement is social and cultural - some of their most important media interests are vested in stories, dreams, music, role play, games, dreams, fantasy.

So I fully agree that the arts is the right place for film education, and for the media arts more generally, where ideally film educators can make common cause with musicians, dramatists, story-makers and visual designers, whose specific art forms also form part of the multimodal assemblage of film. In this sense, film seems to me promiscuous, and while the arts is the best place for it, it is also true that it needs to continue its dialogue with language and literacy on the one hand, and with technology on the other. Film theory has a long love affair with the cinematic apparatus - but the apparatus now includes the computer and the programming languages it employs.

As an example, I will consider the opening sequence from a short animated film made by a class of 11-year-olds in the UK. The film arose from a project funded by First Light, which produced three films in different parts of England, one of which was part of the 'Cinéma, cent ans de jeunesse' programme. This film, however, was a machinima, a form of animation made using the 3D-animation technology of video game environments and characters. The film opens with a girl waiting anxiously with a friend for the arrival of her parents, only to be met by a policeman with news that they have been involved in a plane crash (see Figure 3). 


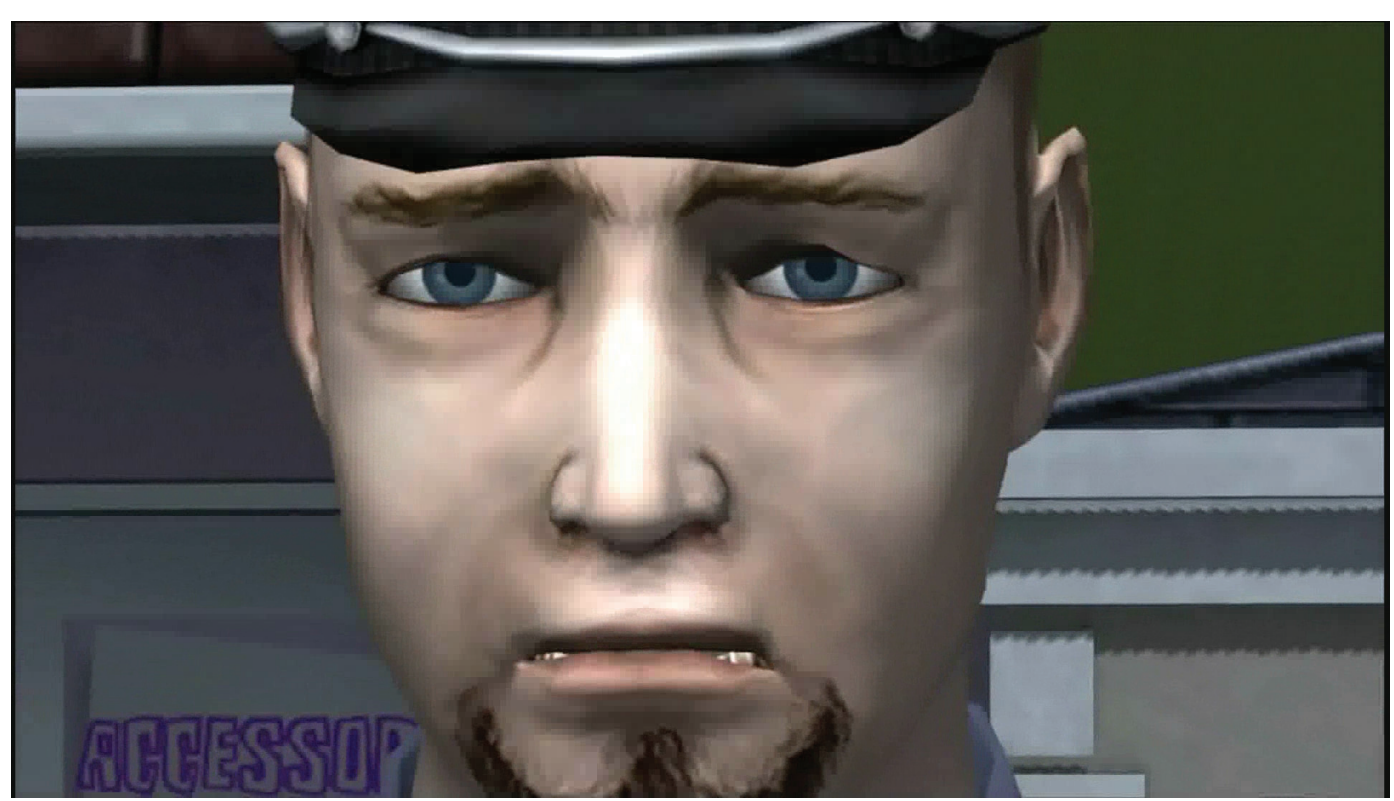

Figure 3: Screengrab of policeman sequence in children's machinima film

The key point is the combination of the arts - a multimodal cross-arts complicity, in which the tragic tones of the policeman's voice, the computer-generated expression on his face, the lyrical tones of the solo violin music and the extreme close-up shot, produce the peculiar, promiscuous intensity characteristic of film. It is a promiscuity that may be realized here in one of the newest kinds of film form, but whose principles of meaning-through-juxtaposition are identical to those elaborated by Eisenstein: multimodal montage. I should add that this project allowed the pedagogies to follow the multimodal artwork - the children worked with teachers of music, media, computing, drama and language, following the second approach I proposed above to uniting critical and creative processes across the constituent modes. The policeman's voice was acted by a boy experienced in drama from an after-school group he attended, while the music was composed and played by a group of children specializing in this aspect of the production. Meanwhile, another pair of children worked on the computer-generated image of the policeman, operating filters within the software to craft his sorrowful expression. This kind of collaboration across the arts, balancing specialist skills against the overall design of the film, is a difficult thing to manage in the fragmented curricula imposed by most national school systems - but we should try for it.

However, the fact that this kind of animation has a kinship with games also needs consideration. The virtual world it constructs, and the characters within it, are constructed in a similar way to the creation of such entities in an online role-playing game, rather than by the traditional processes of stop-frame animation (or even 3D digital animation). The process itself is playful, rather than artisanal, so the cultural function of games needs to be taken into account if we are to understand what kinds of critical understanding and creative practice are going on here.

\section{Finally - 'their' films as other}

I want to end with a rather different argument from Bergala's book. The thrust of the approach recommended throughout the book is an introduction of the 'other' in 
the form of new films children will never have encountered. But this is complemented by a recognition nicely expressed as a rejection of 'From Pokémon to Dreyer' - the condescending idea that children can be fooled into a supposed advanced taste by leading out of their own chosen films. Bergala argues for a different value in using films chosen by students:

The good idea occurred to certain adults ... to ask students to bring to class ... clips from 'their' films. And these same adults were introduced to films of whose existence they had not been aware, visibly belonging to a generationally specific culture; yet the excerpts, inserted into the sequence by students, showed that the class had effectively grappled with the question of off-screen sound (Bergala, 2016: 49).

The exposure to the 'other', then, works both ways - adults can be surprised and educated by young people's choices too. I think many film and media educators would find this a welcome reversal of a common pedagogic practice, and an acknowledgement of the cultural partnership between adults and children that should characterize film and education, and media education more broadly.

I wonder, though, whether such cultural preferences are entirely generational. The judgement of taste in Bourdieu's (1984) classic account is largely determined by social class and the dispositions and cultural capital it confers. And while more recent work in this field has added age, gender and ethnicity to the factors in play (Bennett et al., 2009), class is still significant, and perhaps should be explicitly acknowledged in our efforts to understand what kinds of cultural encounter occur as children and adults experience each other's cinematic choices.

\section{Conclusion: From Cahiers to convergence?}

It's a long haul from Cahiers du cinéma, for which Bergala wrote, to the cacophonous sprawl of YouTube - from the academic dissection of film through découpage to the characteristic mash-up, pastiche and fragmentation of contemporary video culture. Yet it may be possible to have something of both - not to lose the formal emphasis of Bergala's vision, or even its default preference for the European cinematic canon, but at the same time to recognize the cultural affinity young people have with the parodic, improvisatory remix aesthetic of online moving-image making and display. To adapt Bergala's argument a little, the educational merit of doing this is not so much to condescend to young people's taste in the hope of leading them on to the canon. Rather, it is to recognize that film itself as an art form is renewed by such associations. Art-house film has always benefited from a productive overlap with popular cinema (and vice versa); the adaptation trade across film and video game has produced an exchange of style, culture and narrative structure. Meanwhile, the quasi-critical practices of excerption, mash-up, retitling, fan tribute and wicked parody rampant on YouTube and other platforms have offered those who used to be known as audiences, including our students, new tools and cultural templates for dynamic engagement. We would be remiss to pass by the opportunities to incorporate these practices, texts and landscapes into our teaching programmes. The formal exercises of camera and edit suite, and the sober tones of classical film theory, can all survive the shock, and will emerge the better for it. I hope Bergala might agree. 


\section{Notes on the contributor}

Andrew Burn is Professor of English, Media and Drama at UCL Institute of Education. His research focuses on media literacy, play, games, film and animation. He previously taught in UK state schools for 24 years.

\section{References}

Banaji, S., Burn, A. and Buckingham, D. (2007) The Rhetorics of Creativity: A literature review. Creative Partnerships. Online. www.creativitycultureeducation.org/wp-content/uploads/rhetoricsof-creativity-2nd-edition-87.pdf (accessed 14 April 2018).

Barthes, R. (1978) 'The third meaning'. In Barthes, R. Image, Music, Text. Trans. Heath, S. New York: Hill and Wang, 52-68.

Bazalgette, C. (2009) Impacts of Moving Image Education: A summary of research. Scottish Screen. Online. www.scottishscreen.com/images/documents/mie_research_summary.pdf (accessed 14 April 2018).

Bennett, T., Savage, M., Silva, E., Warde, A., Gayo-Cal, M. and Wright, D. (2009) Culture, Class, Distinction. London: Routledge.

Bergala, A. (2016) The Cinema Hypothesis: Teaching cinema in the classroom and beyond. (FilmmuseumSynemaPublikationen 28). Trans. Whittle, M. Vienna: Austrian Film Museum.

Bourdieu, P. (1984) Distinction: A social critique of the judgement of taste. Trans. Nice, R. London: Routledge and Kegan Paul.

Buckingham, D., Grahame, J. and Sefton-Green, J. (1995) Making Media: Practical production in media education. London: English and Media Centre.

Burn, A. (1999) 'Grabbing the werewolf: Digital freezeframes, the cinematic still and technologies of the social'. Convergence, 5 (4), 24-34.

Burn, A. (2006) 'Multi-text magic: Harry Potter in book, film and videogame'. In Collins, F.M. and Ridgman, J. (eds) Turning the Page: Children's literature in performance and the media. Bern: Peter Lang. 227-50.

Burn, A. (2009) Making New Media: Creative production and digital literacies. New York: Peter Lang.

Burn, A. (2014) 'Towards the kineikonic mode: Towards a multimodal approach to moving image media'. In Jewitt, C. (ed.) The Routledge Handbook of Multimodal Analysis. 2nd ed. London: Routledge, 373-83.

Burn, A. (2016) 'Making machinima: Animation, games, and multimodal participation in the media arts'. Learning, Media and Technology, 41 (2), 310-29.

Burn, A. and Durran, J. (2006) 'Digital anatomies: Analysis as production in media education'. In Buckingham, D. and Willett, R. (eds) Digital Generations: Children, young people, and new media. Mahwah, NJ: Lawrence Erlbaum Associates, 273-93.

Burn, A. and Durran, J. (2007) Media Literacy in Schools: Practice, production and progression. London: Sage.

Chandler, P., O'Brien, A. and Unsworth, L. (2009) 'Challenges in the development of a multimedia authoring pedagogy'. Paper presented at the Australian Association for Research in Education, Canberra, November/December.

Chatman, S. (1978) Story and Discourse: Narrative structure in fiction and film. Ithaca, NY: Cornell University Press.

Eisenstein, S.M. (1968) The Film Sense. Ed. and trans. Leyda, J. London: Faber and Faber.

Genette, G. (1980) Narrative Discourse. Oxford: Blackwell.

Johnson, R. (1989) 'Cultural studies in a strong state'. The English Magazine, 22, 10-14.

Kress, G. and van Leeuwen, T. (2001) Multimodal Discourse: The modes and media of contemporary communication. London: Arnold.

Metz, C. (1974) Film Language: A semiotics of the cinema. Trans. Taylor, M. Chicago: University of Chicago Press.

Pasolini, P. (1988) 'The written language of reality'. In Pasolini, P. (Barnett, L.K. (ed.)), Heretical Empiricism. Trans. Lawton, B. and Barnett, L.K. Bloomington: Indiana University Press, 197-222.

Reid, M., Burn, A. and Wall, I. (2013) Screening Literacy: Executive summary. London: British Film Institute. 
Secrethesis.wordpress.com (2011) 'Diagram of Alexander Nevsky Clip by Sergei Eisenstein', 8 March 2011. Online secrethesis.wordpress.com/2011/02/21/pecha-kucha-one/nevsky-diagram-400-b (accessed 16 April 2018).

Sutton-Smith, B. (2001) The Ambiguity of Play. Cambridge, MA: Harvard University Press.

Thompson, K. (1986) 'Teachers as artists'. Art Education, 39 (6), 47-8.

Thomson, P. and Hall, C. (2015) '"Everyone can imagine their own Gellert": The democratic artist and "inclusion" in primary and nursery classrooms'. Education 3-13, 43 (4), 420-32.

Uprichard, E. (2008) 'Children as "being and becomings": Children, childhood and temporality'. Children and Society, 22 (4), 303-13.

van Leeuwen, T. (1985) 'Rhythmic structure of the film text'. In van Dijk, T.A. (ed.) Discourse and Communication: New approaches to the analysis of mass media discourse and communication. Berlin: de Gruyter, 216-32.

Vygotsky, L.S. (1998) 'Imagination and creativity in the adolescent'. In Rieber, R.W. (ed.) The Collected Works of L.S. Vygotsky (Vol. 5). Trans. Hall, M.J. New York: Plenum Press, 151-66.

Wyse, D. (2001) 'Grammar for writing? A critical review of empirical evidence'. British Journal of Educational Studies, 49 (4), 411-27. 